\title{
A Look at Motorcycle Crash Recidivism and a Teachable Moment
}

\author{
${ }^{1}$ Tara Michelle Irani, ${ }^{2}$ Levi Procter, ${ }^{3}$ Carl Schulman, ${ }^{4}$ Lo Kaming, ${ }^{5}$ Edward Lineen, ${ }^{6}$ Patricia Marie Byers
}

\begin{abstract}
Background: In 2000, the Florida helmet law was repealed despite unhelmeted riders being more likely to suffer serious and fatal injuries. Simultaneously, more Florida residents are riding. To reduce motorcycle crash (MCC) recidivism, we implemented a secondary prevention program by educating patients soon after a crash. We predicted a teachable moment that could be used to educate hospitalized riders regarding risk reduction.
\end{abstract}

Study design: Beginning July 2011, MCC patients at a Level 1 trauma center were prospectively studied and educated (>odds ratio $=18$ years, Glasgow Coma Score $=15$ ). Patients completed a survey containing questions about prior crashes, a pretest, a risk assessment/rider responsibility educational module at bedside, a post-test, and were contacted after 3 months to evaluate information retention, using post-test. A paired t-test and Wilcoxon signed-rank test were used to compare scores. Other proportion comparisons were compared using Chi-squared statistics (significance at $p<0.05$ ).

Results: We screened 264 patients and consented 83. Males constituted $89 \%$ (mean age 34), 57 completed the module and 21 completed the follow-up post-test at 3 to 6 months (mean $=4.9$ ). We identified a crash recidivism rate of $45 \%$ (35/77), with $71 \%$ of these crashes requiring hospitalization. Both immediate and follow-up post-tests revealed retention of safety information \{baseline pretest, $\mathrm{n}=57$ [standard deviation (SD)] 3.53/6 (1.38); post-test, $n=57$ (SD) 5.56/6 (0.78) $p<0.0001$; follow-up test, $n=17$ median interquartile range $5 / 6(1) p=0.0009\}$.

Conclusion: Almost half of all MCC victims have been in previous crashes and could benefit from a secondary prevention educational program in trauma centers. Patients in MCCs can be provided a brief safety intervention to increase their knowledge of risk reduction management above baseline.

Keywords: Trauma, Prevention, Motorcycle, Recidivism, Teachable moment, Helmet, Education.

\footnotetext{
${ }^{1}$ Assistant and Coordinator, ${ }^{2}$ Surgeon, ${ }^{3,6}$ Professor ${ }^{4}$ Biostatistician, ${ }^{5}$ Assistant Professor

${ }^{1-3,5,6}$ Department of Surgery, University of Miami Miller School of Medicine, Florida, United States
}

${ }^{4}$ Department of Public Health Sciences, University of Miami Miller School of Medicine, Florida, United States

Corresponding Author: Tara Michelle Irani, Assistant and Coordinator, Department of Surgery, University of Miami Miller School of Medicine Florida, United States, Phone: 3019968322, e-mail: tirani@med.miami.edu
How to cite this article: Irani TM, Procter L, Schulman C, Kaming $L$, Lineen E, Byers PM. A Look at Motorcycle Crash Recidivism and a Teachable Moment. Panam J Trauma Crit Care Emerg Surg 2014;3(2):43-46.

Source of support: The florida department of transportation.

Conflict of interest: None

\section{RESUMEN}

Antecedentes: En el año 2000, la Ley de cascos de la Florida (Florida Helmet Law) fue abolida a pesar de que los motociclistas que no usan casco son más propicios a sufrir lesiones más serias y mortales. Simultáneamente, el número de motociclistas en la Florida ha aumentado. Para reducir la reincidencia de accidentes de motocicletas (MCC, por sus siglas en inglés), hemos implementado un programa secundario de prevención que educa a los pacientes poco después de un accidente. Pronosticamos un momento apropiado para educar a los motociclistas hospitalizados sobre la reducción de riesgos.

Diseño del estudio: Comenzando en Julio de 2011, los pacientes involucrados en un MCC en un centro de trauma a Nivel 1 fueron estudiados e instruidos (coeficiente de probabilidad = 18 años, Puntaje en la Escala de Coma Glasgow = 15). Los pacientes completaron una encuesta que contiene preguntas sobre accidentes previos, una evaluación inicial, un módulo educativo junto a su cama de evaluación de riesgo/ responsabilidad del motociclista, una evaluación posterior, y se les contactó 3 meses más tarde para evaluar la información retenida mediante el uso de una prueba de seguimiento. Se usó un t-test y una prueba de Wilcoxon para datos emparejados para comparar puntajes. Se hicieron otras comparaciones de proporción con utilizando pruebas estadísticas de $\mathrm{X}^{2}$ (significativa con una $\mathrm{p}<0.05$ ).

Resultados: Se seleccionaron 264 pacientes y 83 dieron su consentimiento. El 89\% eran hombres (edad media 34), 57 completaron el módulo y 21 completaron la prueba posterior de seguimiento a 3 a 6 meses (media $=4.9$ ). Identificamos un rango de reincidencia de accidentes de 45\% (35/77), de estos el $71 \%$ de estos accidentes necesitó hospitalización. Tanto la prueba posterior inmediata como la de seguimiento revelaron retención de la información de seguridad (prueba previa de punto de inicial, $\mathrm{n}=57$ [desviación estándar] (SD por sus siglas en inglés)] 3.53/6 (1.38); prueba posterior, $n=57$ (SD) 5.56/6 $(0.78) p<0.0001$; prueba de seguimiento, $n=17$ rango medio inter-cuartil 5/6 (1) $p=0.0009)$.

Conclusión: Casi la mitad de las víctimas de MCC han tenido accidentes previos y se podrían beneficiar de un programa secundario de prevención en los centros de trauma. A los pacientes en los MCC se les puede proporcionar una breve intervención de seguridad para aumentar su conocimiento para lograr reducción de riesgos en el punto de partida. 
Palabras claves: Trauma, Prevención, Motocicleta, Reincidencia, Momento apropiado para educar, Casco, Educación.

\section{INTRODUCTION}

Motorcycle crashes (MCCs) and scooter crashes represent an increasingly high injury burden on the health care system throughout the United States. It has been reported that $80 \%$ of MCCs result in injury or death, substantially higher than the $20 \%$ incidence of injury or death associated with motor vehicle crashes. ${ }^{1}$ According to the centers for disease control and prevention (CDC) and the National center for injury prevention and control (NCIPC), motorcycle safety how to save lives and save money, ${ }^{2}$ from 1997 to 2008, motorcyclerelated deaths have increased annually, possibly due to increased ridership in response to steadily rising fuel costs.

Motorcycle-related trauma has become a health care burden at both the national and state levels. The number of Florida residents buying, riding, and registering motorcycles and scooters in the state of Florida continues to increase. ${ }^{3}$ In 2000, Florida repealed its universal helmet law. Currently, the law mandates helmet use for riders under the age of 21 and those with less than $\$ 10,000$ of medical insurance coverage. ${ }^{4}$ Comparing the 30 months after the Florida state legislature repealed its universal helmet law with the 30 months before repeal, deaths of all riders increased by $55 \%$, substantially higher than what was expected from the increased registrations after repeal. ${ }^{5}$ Motoreycle crashrelated hospitalizations increased by more than $40 \%$. Among riders under the age of 21 , deaths of unhelmeted riders increased by $188 \%$, even though the helmet law still applied to them. ${ }^{5}$ This is due to the issue that identifying partial law violations is problematic: compliance is low because partial helmet laws are difficult to enforce. As a result, partial helmet laws are typically only enforced when a police officer has pulled a rider over for another infraction, such as speeding. ${ }^{6}$

On July 1, 2008, an endorsement (a specialized license with an educational requirement) was mandated in an attempt to decrease MCCs for bikes with engines over $49 \mathrm{~cm}^{3}$ The endorsement requires all new applicants to have standardized basic training in riding technique and risk reduction. Since, this new legislation, the number of people becoming endorsed in Florida rose from 924,746 in 2008 to $1,042,811$ in 2011 . $^{?}$

In studies where motorcycle riders are surveyed, it is evident that motorcycle riders tend to get in multiple crashes and it has been reported that those motorcycle riders are less likely to wear helmets. ${ }^{8}$ We hypothesized that MCC recidivism was underappreciated by the trauma community and would offer an opportunity for secondary prevention. To begin to evaluate whether trauma centers could help to decrease the high MCC and fatality rates, we implemented a pilot program to study crash recidivism and the teachable moment by educating patients about riding decisions soon after a MCC or scooter crash. Our goal was to provide a brief safety intervention to increase each patient's knowledge of risk reduction management. We also compared the crash recidivism rate as per patient history and compared it to data from our trauma registry.

The teachable moment is a secondary prevention strategy that aims at educating a person about his/her past and future decisions because of a recent harmful event. The concept of the teachable moment has been discussed in preventative research. Studies address this concept differently, though the goal is the same: to prevent recidivism. A comprehensive study by the national institutes of health titled teachable moments for health behavior change: a concept analysis, by Lawson and Flocke, ${ }^{9}$ discusses how the teachable moment has been applied in different studies. Patterns were derived from this comprehensive review and this study concludes that the use of the term teachable moment falls into three categories: first, the teachable moment that is synonymous with 'opportunity' (81\%); second, the use in any context that leads to a higher than expected behavior change is also retrospectively labeled a 'teachable moment' (17\%); and finally, a phenomenon that involves a cueing event that prompts specific cognitive and emotional responses (2\%). In addition, they conclude that the teachable moment is not necessarily unpredictable or a combination of situational factors that prompt behavior change, but rather, it is the clinician-patient interaction that may create the teachable moment, and that this interaction may be central to the creation of teachable moments for health behavior change. ${ }^{9}$ These findings are consistent with how we chose to utilize the teachable moment in our study. We made use of the opportunity to educate MCC victims on motorcycle safety when victims are most aware of its importance. The crash is a phenomenon that may cue an improvement in these motorcycle riders' habits of risk reduction, in the hope of decreasing recidivism.

We hypothesized that crash recidivism is significant, that a teachable moment could be used to educate hospitalized riders regarding these factors, and that safety gear usage would vary for patients based on a history of MCC injuries.

\section{MATERIALS AND METHODS}

At Ryder Trauma Center in Miami, Florida, from July 2011 to December 2012, MCC patients aged 18 and over with a Glasgow Coma Score of 15 were prospectively identified and asked to consent to study participation. Each patient was asked to complete a survey about riding experience, gear usage and prior crashes. This was followed by a pretest that 
included questions about rider risks, crash causes, safe riding habits, and alcohol use. Following the pretest, a 30 minutes presentation was given at bedside reviewing risk assessment, rider responsibility, safety gear, and crash causality. All pretest topics were covered during the educational module. In conclusion of this module, patients completed a post-test comprised of questions about information covered during the educational model.

And in summary of post-test, patients were provided safety handouts, which included the Motorcycle Safety Foundation's T-CLOCS preride inspection checklist, helmet and protective gear information, and endorsement information. Patients were then asked to participate in a follow-up assessment. Those that agreed were contacted between 3 and 6 months after discharge (mean 4.9 months) for a phone survey in which they repeated the post-test to evaluate retention.

Simultaneously, we retrospectively reviewed our trauma center registry for MCCs from September 1992 to December 2011. We identified 3,555 MCCs and searched the results by name, social security number, and date of birth to identify MCC recidivism.

A paired t-test and Wilcoxon signed-rank test were used to compare scores. Other proportion comparisons were compared using Chi-squared statistics.

\section{RESULTS}

The total number of patients screened for inclusion in the study was 264 . Of those, 83 (31\%) consented to participate. A total of 77 patients were surveyed and 57 completed both the pretest and post-test. And 21 patients completed the longterm follow-up (Table 1). The mean age of prospectively studied patients was 34 years and $89 \%$ were male.

Table 1: Group quantities

\begin{tabular}{ll}
\hline Screened & 264 \\
Consented & 83 \\
Surveyed & 77 \\
Module with post-test only & 57 \\
Module with 3-6 month follow-up & 21 \\
\hline
\end{tabular}

Table 2: Helmet usage and prior crash results

\begin{tabular}{llll}
\hline Helmet usage & Prior crash & No prior crash & p-value \\
\hline Yes & 18 & 19 & \\
No & 17 & 23 & 0.59 \\
\hline
\end{tabular}

Table 3: Pretest, post-test, and follow-up scores

\begin{tabular}{lll}
\hline $\begin{array}{l}\text { Pretest } \\
(n=57)\end{array}$ & $\begin{array}{l}\text { Post-test } \\
(n=57)\end{array}$ & $\begin{array}{l}\text { Follow-up test } \\
(n=17)\end{array}$ \\
mean (SD) & mean (SD) & median (IQR) \\
\hline $3.53 / 6(1.38)$ & $5.56 / 6(0.78)$, & $5 / 6(1)$, \\
& $p<0.0001$ & $p=0.0009$ \\
\hline
\end{tabular}

IQR: Interquartile range; SD: Standard deviation
The overall crash recidivism rate was much higher based survey data compared to the rate identified in our trauma registry. From the Ryder Trauma Center registry database, we identified a crash recidivism rate of $1.5 \%$ (54 out of 3,555 patients). Among the prospectively collected patients, the recidivism rate was $45 \%$ (35 out of 77 patients), with $71 \%$ of these crashes resulting in hospitalization.

Of the 77 riders surveyed, 37 (48\%) stated that they were wearing a helmet at the time of their crash. A total of 18 riders $(23 \%)$ had been in a prior crash, while $19(25 \%)$ had not. And 40 patients $(52 \%)$ denied helmet use at the time of their crash. Of these, $17(22 \%)$ had been in a prior crash and $23(30 \%)$ had not. There was no significant difference in helmet usage for riders in a prior crash when compared with those with no history of prior crash, $\mathrm{p}=0.59$ (Table 2).

The mean score on the pretest was $3.53 / 6$ with a standard deviation (SD) of 1.38. This level of baseline knowledge regarding risk reduction was lower than we had expected. There was significant improvement, however, on the posttest with a mean score of 5.56/6 and a SD of $0.78(\mathrm{p}<0.001)$. The mean score on the follow-up test (given 3-6 months after discharge) was $5 / 6$ with a SD of 1 . This also showed significant improvement from pretest performance $(\mathrm{p}=$ 0.009). Both immediate and follow-up post-tests revealed retention of safety information (Table 3 ).

\section{DISCUSSION}

Based on our findings, MCC recidivism is greatly underestimated by trauma center data registries. In patients surveyed, crash recidivism was $45 \%$ with the majority requiring hospitalization, allowing for participation in a hospital-based teachable moment intervention. In addition, most riders had poor baseline knowledge of risk reduction strategy at the time of their crashes and significantly increased their knowledge after the educational module. This knowledge was significantly retained in a follow-up survey after 3 to 6 months, clearly demonstrating risk reduction data acquisition.

We were unable to demonstrate a decrease in motorcycle helmet compliance in riders who had been in a prior crash. While the study by Mangus et al was a survey of all riders at a bike event, ours was of riders who have crashed, were in the hospital, and consented to participate in a research study. This may have introduced bias into the surveyed population. In addition, these differences may be due to the smaller numbers of riders surveyed in our study when compared with the data from Mangus et al. ${ }^{8}$ Despite our efforts, we were unable to get long-term follow-up surveys from all the patients. The long-term retention of the learned material may also be biased by patient self-selection and willingness to participate in follow-up. Although, this may be perceived as 
a study limitation, educational programs will always have inherent bias based on student participation and cannot be as effective as enforced legislation across populations.

CDC and NCIPC claim that MCCs and fatalities are increasing and represent a major public health concern. In addition to the high injury burden, MCCs represent a significant financial burden to the nation. They consume significant public funds for emergency response, emergency room costs, and insurance premiums. ${ }^{10}$ Compounding this issue, unhelmeted motorcycle riders are less likely to have health insurance and will, therefore, require their medical expenses, to be paid by government-funded healthcare. A study conducted at a major trauma center determined that of 105 hospitalized motorcyclists, $63 \%$ of their care was paid for by public funds, with over half of these charges covered by Medicaid. ${ }^{11}$

In Florida, the total hospital charges for the initial treatment of motorcyclists injured in traffic crashes in 2011 were $\$ 411,783,763$. However, years of life lost, prehospital expenses, rehabilitation, and long-term care costs were not taken into account, making the financial burden much greater than this documented value. In 2009 , over $40 \%$ of motorcyclist hospitalizations and emergency department visits were not covered by commercial insurance and from 17 to $30 \%$ of patients were underinsured or self-paid. ${ }^{7}$

According to the CDC and NCIPC, because motorcycle ownership is at an all-time high, motorcycle-related deaths and traumatic injuries will remain high unless successful preventive measures are developed. In Florida, the crash and fatality rates are higher than the national average. We have demonstrated that many motorcyclists who crash have a poor understanding of risk reduction and are recidivists. The inpatient care after these crashes provides an opportunity to analyze their risk factors and provide safety education that is retained for several months. This education may offer a teachable moment that may alter behavior and lessen recidivism. More research is needed to evaluate the effects of this education on risk reduction and injury burden. In addition, studies looking at target populations that would most benefit from such education are needed.

\section{REFERENCES}

1. The National Highway Traffic Safety Administration Motorcycle Safety Program. Washington, DC: National Highway Traffic Safety Administration, US Department of Transportation; 2003 Oct.

2. Motorcycle Safety: How to Save Lives and Save Money. US Department of Health and Human Services, Centers for Disease Control and Prevention, National Center for Injury Prevention and Control. Available at: http://www.cdc.gov/ Motorvehiclesafety/pdf/motorcycle_brief-a.pdf.

3. Florida Department of Highway Safety and Motor Vehicles [Internet]. Available at: http://www.flhsmv.gov.

4. Insurance Institute for Highway Safety. History of US motorcycle laws and changes in coverage. Arlington (VA): Insurance Institute for Highway Safety, Highway Loss Data Institute; 2011. Available at: http://www.iihs.org/laws/helmet_history.html.

5. National Highway Traffic Safety Administration. Fatality Analysis Reporting System: 2008. Washington DC: National Highway Traffic Safety Administration, US Department of Transportation 2008.

6. Houston DJ, Richardson LE Jr. Motorcycle safety and the repeal of universal helmet laws. Am J Public Health 2007 Nov;97(11):2063-2069.

7. Ride Smart Florida [Internet]. Available at: http://www. ridesmartflorida.com.

8. Mangus RS, Simons CJ, Jacobson LE, Streib EW, Gomez GA. Current helmet and protective equipment usage among previously injured ATV and motorcycle riders. Inj Prev 2004 Feb;10(1):56-58.

9. Lawson PJ, Flocke SA. Teachable moments for health behavior change: a concept analysis. Patient Educ Couns 2009 Jul;76(1):25-30.

10. Derrick AJ, Faucher LD. Motorcycle helmets and rider safety: a legislative crisis. J Public Health Policy 2009 Jul;30(2):226-242.

11. Rivara FP, Dicker BG, Bergman AB, Dacey R, Herman C. The public cost of motorcycle trauma. JAMA $1988 \mathrm{Jul}$ 8;260(2): 221-223. 